\title{
Development and optimization of a generic HPLC method for the simultaneous determination of common ingredients in multi component cough and cold oral drug products using chemometrics
}

\author{
Marija Zafirova ${ }^{1 *}$, Jelena Acevska ${ }^{2}$, Liljana Ugrinova ${ }^{1}$, \\ Gabriela Petrovska-Dimitrievska ${ }^{1}$, Vasil Karchev ${ }^{1}$, Natalija Nakov ${ }^{2}$, \\ Katerina Brezovska ${ }^{2}$, Aneta Dimitrovska ${ }^{2}$, Rumenka Petkovska ${ }^{2}$, \\ Liljana Anastasova ${ }^{2}$, Jasmina Tonic-Ribarska ${ }^{2}$, Ana Poceva Panovska ${ }^{2}$, \\ Zoran Kavrakovski ${ }^{2}$, Suzana Trajkovic-Jolevska ${ }^{2}$ \\ ${ }^{1}$ Center for Drug Quality Control, Faculty of Pharmacy, \\ Ss. Cyril and Methodius University, Majka Tereza 47, 1000 Skopje, \\ Republic of Macedonia \\ ${ }^{2}$ Institute of Applied Chemistry and Pharmaceutical Analysis, Faculty of Pharmacy, \\ Ss. Cyril and Methodius University, Majka Tereza 47, 1000 Skopje, \\ Republic of Macedonia
}

\begin{abstract}
The aim of this work was to develop a single, generally applicable high performance liquid chromatography/diode array detector (HPLC/DAD) method for simultaneous determination of the most frequently used cough and cold active substances and their impurities that would be applicable for a number of possible formulation compositions of cough and cold medicines. The compounds that are separated by the method include eleven active substances: paracetamol, phenylephrine $\mathrm{HCl}$, caffeine, ibuprofen, ascorbic acid, propiphenazone, pheniramine maleate, chlorphenamine maleate, pseudoephedrine $\mathrm{HCl}$, dextromethorphan $\mathrm{HBr}$ and cetylpyridinium $\mathrm{Cl}$; five of their impurities: 4-aminophenol, 4-nitrophenol, 4`-chloroacetanilide, chlorphenamine impurity $\mathrm{C}$ and ephedrine $\mathrm{HCl}$; and two preservatives: sodium benzoate and propyl parahydroxybenzoate. All 18 compounds were successfully separated on a reversed phase (RP)-HPLC column with superficially porous particles using gradient elution with a very simple mobile phase in 14 minutes with excellent sensitivity and resolution. Method optimization was performed by the design of experiments approach. The proposed method has been validated according to ICH guidelines and proved to be suitable for the simultaneous qualitative and quantitative determination of the selected compounds in different cough and cold dosage forms.
\end{abstract}

Keywords: cough and cold active substances and impurities, HPLC/DAD, superficially porous particles, core-shell particles, chemometrics, design of experiments

\footnotetext{
*marijazafirova@ff.ukim.edu.mk
} 


\section{Abbreviations}

4-AMPH - 4-aminophenol, 4-CHLAC - 4'chloroacetanilide, 4-NITPH - 4-nitrophenol, ASCAC Ascorbic acid, CAF - Caffeine, CCF - Central Composite Face Centered, CETPYR - Cetylpyridinium chloride, CHLIMPC - Chlorphenamine impurity C, CHLPHE Chlorphenamine maleate, DEXMETH Dextromethorphan hydrobromide, DoE - Design of experiments, EPHED - Ephedrine hydrochloride, HPLC/DAD - High performance liquid chromatography/diode array detector, IBU - Ibuprofen, MALAC - Maleic acid, NaBENZ - Sodium benzoate, OTC - Over-the-counter, PAR - Paracetamol, PHEN Pheniramine maleate, PHEPH - Phenylephrine hydrochloride, PPHB - Propyl parahydroxybenzoate, PROPHE - Propiphenazone, PSEEPH - Pseudoephedrine hydrochloride, RP - Reversed phase, $\mathrm{R}_{\mathrm{S}}$ - Resolution, UPLC - Ultra performance liquid chromatography.

\section{Introduction}

The cough and cold category represents a large part of over-the-counter (OTC) medicines, and encloses a vast and diverse array of pharmaceutical formulations usually containing a combination of two or more active ingredients that target multiple symptoms at once. The most frequently used formulations comprise a combination of a decongestant, antihistamine, analgesic, antitussive and according to the pharmaceutical form may contain preservatives in addition to numerous excipients (Table 1) (Van Schoor, 2013). The analytical methods used for the quality control of these medicines usually devote to one component at a time, so the analytical work involves several different methods and is time consuming. In the literature numerous and different analytical techniques have been reported for the determination of cough and cold ingredients such as ultraviolet-visible spectroscopy, thin layer chromatography, gas chromatography, gas chromatography with mass spectroscopy, capillary electrophoresis, multivariate spectrophotometric method, and as the most widely used HPLC with ultraviolet, fluorescence or mass spectroscopy (Acheampong et al., 2016; Dewani et al., 2014, 2015; Hasan et al., 2016; Ibrahim et al., 2015; Marin et al., 2002; Palabiyik and Onur, 2010; Sawant and Borkar, 2011, 2015; Sehrawat et al., 2013; Xuan et al., 2013).

Having a common, reliable, fast and efficient method for the most frequently encountered compounds and their impurities in multi-component cough and cold combinations that could be used for their simultaneous quantitative determination and would be applicable to different dosage forms offers a benefit in the quality control of these preparations, reducing time and cost of the analysis. Also, the very current and worrying problem of falsified medicines could have great use of an allencompassing method that could be used for screening and quantifying components of dubious samples of medicines. Its use could further be broadened to detecting these active substances in natural products for cough and cold treatment where they should not be present.

At present time HPLC is the most exploited and commonly available method that would be a method of choice for simultaneous determination of large number of analytes as is the case with cough and cold formulations. Literature scouting reveals few HPLC methods using core-shell technology and ultra performance liquid chromatography (UPLC) methods that can be applied for simultaneous determination of different combinations of cough and cold active substances and their impurities (Dewani and Patra, 2015; Grumbach et al., 2007; Pedije, 2011; Phenomenex, 2009; Trass and Lomas, 2015; Waters, 2014; Yehia and Essam, 2016). Nevertheless, to the best of our knowledge, so far no single HPLC method has been reported that could be used to determine all of the undermentioned compounds in different cough and cold dosage forms.

The aim of this work was to develop a single, generally applicable, fast and simple method for simultaneous determination of the most frequently used cough and cold active substances and their impurities that would be applicable for a number of possible formulation compositions. In order to obtain an RP-HPLC method which offers the separation and quantification of eleven active substances, five of their impurities and two preservatives (Table 2) the power and advantages of coreshell technology will be acquired. The design of experiments approach would be used for optimization of the proposed method.

\section{Material and methods}

\section{Materials}

Working standards of the following substances: PAR, PHEPH (generously provided by Chemax Pharma, Bulgaria), CAF, IBU, ASCAC, PHEN, PROPHE, PSEEPH, DEXMETH, PPHB, NaBENZ (generously provided by Alkaloid, Skopje, Macedonia), CETPYR (generously provided by Suyog Life Sciences Pvt. Ltd., India) were used. Chemical reference material of CHLPHE was obtained from Sigma-Aldrich. Pro analysi grade of the impurities 4-AMPH (obtained from Merck, Germany), 4-NITPH (obtained from Acros Organics, USA), 4-CHLAC (obtained from Sigma-Aldrich, USA) and the counter ion maleic acid (MALAC) (obtained from Sigma-Aldrich, USA) were used. Chemical reference substances of the impurities CHLIMPC and EPHED were obtained from the European Directorate for the Quality of Medicines. 


\section{Reagents}

Acetonitrile (HPLC grade) was purchased from Carlo Erba Reagents, Val de Reuil, France, and formic acid 98$100 \%$ (for analysis) was purchased from Merck, Darmstad, Germany. Water (highly purified) was obtained with a TKA-LAB Reinstwasser system (Niederelbert, Germany).

\section{Standard solutions}

Method development and optimization was done on a standard solution prepared in the following manner: stock standard solutions of each substance were prepared at a concentration of $1 \mathrm{mg} / \mathrm{mL}$ by dissolving each substance separately in a mixture of $50: 50 \quad(\% \mathrm{v} / \mathrm{v})$ water : acetonitrile. The standard solution was a mixture of each of the individual stock solutions prepared by diluting the stock solutions with diluent (solvent $\mathrm{A}$ : solvent $\mathrm{B}=99.9: 0.1(\% \mathrm{v} / \mathrm{v}))$ to a final concentration of $47.6 \mu \mathrm{g} / \mathrm{mL}$ of each substance.

The final method conditions were confirmed on a system suitability solution prepared as a mixture of each of the individual stock solutions by diluting them with diluent to a final concentration of $25 \mu \mathrm{g} / \mathrm{mL}$ of ASCAC, PPHB, CAF, CHLPHE, NaBENZ, PHEN and MALAC, $50 \mu \mathrm{g} / \mathrm{mL}$ of PAR, PROPHE, PHEPH, PSEEPH, IBU, CETPYR and DEXMETH, and $5 \mu \mathrm{g} / \mathrm{mL}$ of 4-AMPH, 4NITPH, 4-CHLAC, EPHED and CHLIMPC.

\section{Sample preparation}

Three OTC formulations obtained from a local pharmacy were analysed. OTC formulation 1 was a syrup containing the active substances PAR, CHLPHE, DEXMETH and PSEEPH with a declared content of $160 \mathrm{mg}, 1 \mathrm{mg}, 5 \mathrm{mg}$ and $15 \mathrm{mg}$ per $5 \mathrm{~mL}$ syrup, respectively. Sample solution of OTC formulation 1 for the quantitation of CHLPHE, DEXMETH and PSEEPH was prepared by diluting the syrup with diluent (solvent A : solvent $\mathrm{B}=99.9: 0.1(\% \mathrm{v} / \mathrm{v}))$ to a final concentration of the substances in solution: $10 \mu \mathrm{g} / \mathrm{mL}$ of CHLPHE, $50 \mu \mathrm{g} / \mathrm{mL}$ of DEXMETH and $150 \mu \mathrm{g} / \mathrm{mL}$ of PSEEPH (OTC1 Sample solution I). Sample solution of OTC formulation 1 for the quantitation of PAR was prepared by further diluting OTC1 Sample solution I with diluent to a final concentration of $100 \mu \mathrm{g} / \mathrm{mL}$ (OTC1 Sample solution II).

OTC formulation 2 were sachets with powder for oral solution containing the active substances PAR and PHEPH, with a declared content of $1000 \mathrm{mg}$ and $12.2 \mathrm{mg}$ per sachet, respectively. Sample solution of OTC formulation 2 for the quantitation of PHEPH was prepared by weighing an appropriate amount of the powder and dissolving it in water : acetonitrile $=50: 50$ (\% v/v), mixing for 30 minutes in an ultrasonic bath, to obtain a final concentration of the substance of $50 \mu \mathrm{g} / \mathrm{mL}$ (OTC2 Sample solution I). To the solution was added $1 \mathrm{~mL}$ of $1 \mathrm{M} \mathrm{HCl}$, in order to obtain good peak shape of
PHEPH. Sample solution of OTC formulation 2 for the quantitation of PAR was prepared by further diluting OTC2 Sample solution I with diluent to a final concentration of $200 \mu \mathrm{g} / \mathrm{mL}$ (OTC2 Sample solution II).

OTC formulation 3 were film-coated tablets containing the active substances IBU and PAR, with a declared content of $200 \mathrm{mg}$ and $500 \mathrm{mg}$ per tablet, respectively. Sample solution of OTC formulation 3 for the quantitation of IBU and PAR was prepared by letting one tablet (accurately weighed) disintegrate in a small amount of water, and then dissolving it in acetonitrile : water $=80: 20(\% \mathrm{v} / \mathrm{v})$, mixing for 60 minutes in an ultrasonic bath. This solution was further filtered through a $0,45 \mu \mathrm{m}$ PTFE filter and diluted with diluent to a final concentration of the substances of $40 \mu \mathrm{g} / \mathrm{mL}$ and $100 \mu \mathrm{g} / \mathrm{mL}$, respectively (OTC3 Sample solution).

\section{Chromatographic conditions}

The study was done on an Agilent 1260 Infinity system, equipped with a G1311B quaternary pump, G7167A multisampler, G1316A column compartment and G7117A 1290 DAD detector. The chromatographic separation was achieved on a Poroshell 120 EC-C8 $50 \mathrm{~mm} \times 4.6 \mathrm{~mm}$ i.d., $2.7 \mu \mathrm{m}$ particle size, chromatographic column (Agilent Technologies). The mobile phase consisted of solvent A $(0.1 \%(\mathrm{v} / \mathrm{v})$ formic acid $(\mathrm{HCOOH})$ in water $)$ and solvent $\mathrm{B}$ $(0.1 \%(\mathrm{v} / \mathrm{v})$ formic acid in acetonitrile), filtered through a $0.45 \mu \mathrm{m}$ filter. The optimised conditions of the gradient used are the following: $0-1 \mathrm{~min} 0.1 \%$ solvent $\mathrm{B} ; 1-3 \mathrm{~min}$ from 0.1 to $15 \%$ solvent $\mathrm{B} ; 3-11$ min from 15 to $90 \%$ solvent $\mathrm{B} ; 11-12$ min from $90 \%$ back to $0.1 \%$ solvent $\mathrm{B}$ and stabilisation from $12-14$ min with $0.1 \%$ solvent $B$. The flow rate was kept at $1.0 \mathrm{~mL} / \mathrm{min}$ and the column temperature at $35{ }^{\circ} \mathrm{C}$. Injection volume was $1 \mu \mathrm{l}$. The substances were detected at $265 \mathrm{~nm}$, using reference wavelength $450 \mathrm{~nm}$ and bandwidth $100 \mathrm{~nm}$ (ASCAC, PAR, PHEN, PROPHE, CETPYR, PPHB, CAF, CHLPHE, 4-AMPH, 4-NITPH, 4-CHLAC, CHLIMPC) and at $215 \mathrm{~nm}$ using reference wavelength $450 \mathrm{~nm}$ and bandwidth $100 \mathrm{~nm}$ (PHEPH, PSEEPH, NaBENZ, DEXMETH, IBU, EPHED), with a sampling rate of 20 Hz. Data were acquired and processed by use of OpenLAB CDS, ChemStation Edition software (Agilent Technologies).

\section{Method validation}

Method validation was carried out according to ICH (International Conference on Harmonization, 2005) and other appropriate guidelines (Barwick, 2003; FDA, 1994, 2015; Little, 2015; Shabir, 2004; USP 40-NF 35, 2017) determining: specificity, linearity, accuracy, precision, detection limit and quantification limit of the method.

\section{Chemometrics}

The optimization of the experimental factors through 
M. Zafirova, J. Acevska, L. Ugrinova, G. Petrovska-Dimitrievska, V. Karchev, N. Nakov, K. Brezovska, A. Dimitrovska, R. Petkovska, L. Anastasova, J. Tonic-Ribarska, A. Poceva Panovska, Z. Kavrakovski,

Table 1. Most frequently used active substances and their combinations in cough and cold preparations

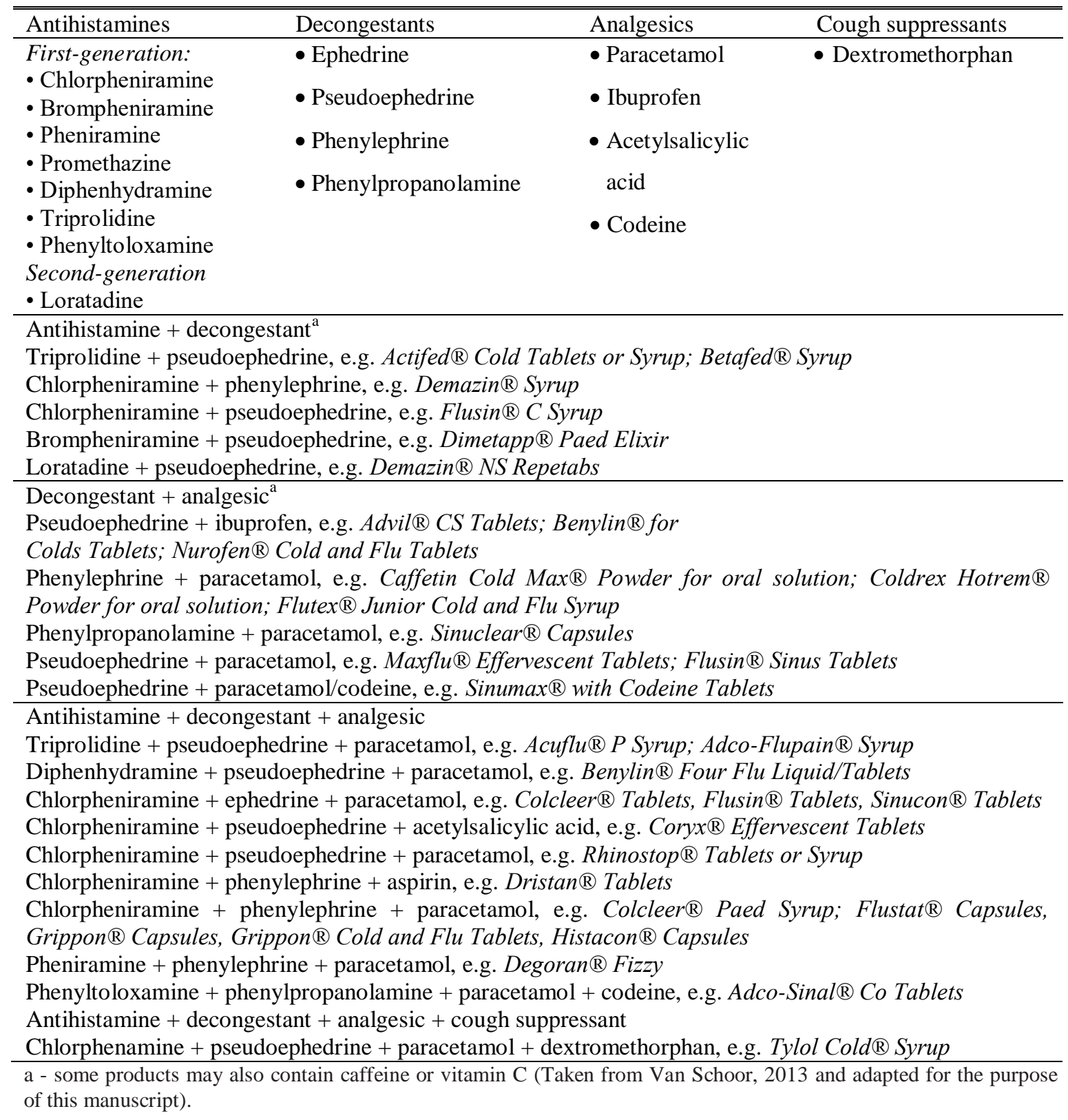

design of experiment methodology was done using MODDE 10.1 Software for design of experiments and optimization (Umetrics, Umea, Sweden). The designed experiments were conducted on a standard solution consisted of all of the forementioned substances.

\section{Results and discussion}

Considering that the goal was to come up with a fast and simple RP-HPLC method that would be useful in the everyday of the analytical laboratory, the method aimed to encompass as many of the most frequently analysed compounds in cough and cold preparations. Conducting a screen of the registered products on several pharmaceutical markets it was concluded to focus on 11 active substances, 5 of their impurities and 2 preservatives.

\section{Definition of preliminary chromatographic conditions}

Looking at the structural formulas of the compounds and their broad polarity range (Table 3), and the complexity of the mixture that should be analysed, one can easily conclude that a gradient elution is inevitable. The starting point of the gradient conditions was chosen according to general literature guidelines and having a fast 
and simple method in mind. The initial method development was started with a typical scouting gradient at room temperature, using $0.1 \%(\mathrm{v} / \mathrm{v})$ formic acid in water as solvent $\mathrm{A}$ and $0.1 \%(\mathrm{v} / \mathrm{v})$ formic acid in acetonitrile as solvent B. Acetonitrile-water is recommended as mobile phase, because of its lower viscosity (and lower pressure drop). The $\mathrm{pH}$ value of the mobile phase (both solvent A and solvent B) was below $\mathrm{pH}<3$, which was suitable for two reasons. First, the $\mathrm{pKa}$ values of both acids and bases will differ from the mobile phase $\mathrm{pH}$ by $>2$ units, thus providing a preferably more robust method that would resist small $\mathrm{pH}$ changes, and second, bases are usually best separated at low $\mathrm{pH}$, because undesirable interactions between sample molecules and the column packing (i.e. silanols) are suppressed, thereby minimizing peak tailing and maximizing column plate numbers (ChromAcademy; Dolan and Snyder, 2000; Snyder et al., 2010). To achieve desired separation a column that uses superficially porous particles as the packing material was used. Core-shell silica particles which already have an extensive and successful background as packing materials for HPLC columns (Hayes et al., 2014), proved efficient for the purpose of this study to obtain suitable separation with a fast flow rate and relatively low back pressure.

Table 2. Active substances, impurities and preservatives included in the developed method

\begin{tabular}{l}
\hline Active substances \\
\hline 1.Paracetamol (PAR) \\
2.Phenylephrine hydrochloride (PHEPH) \\
3.Caffeine (CAF) \\
4.Ibuprofen (IBU) \\
5.Ascorbic acid (ASCAC) \\
6.Propiphenazone (PROPHE) \\
7.Pheniramine maleate (PHEN) \\
8.Chlorphenamine maleate (CHLPHE) \\
9.Pseudoephedrine hydrochloride (PSEEPH) \\
10.Dextromethorphan hydrobromide (DEXMETH) \\
11.Cetylpyridinium chloride (CETPYR) \\
\hline Impurities of paracetamol \\
\hline 12.4-aminophenol (4-AMPH) \\
13.4-nitrophenol (4-NITPH) \\
14.4-chloroacetanilide (4-CHLAC) \\
\hline Impurities of chlorphenamine maleate \\
\hline 15. Chlorphenamine impurity C (CHLIMPC) \\
\hline Impurities of pseudoephedrine hydrochloride \\
\hline 16.Ephedrine hydrochloride (EPHED) \\
\hline Preservatives \\
\hline 17.Propyl parahydroxybenzoate (PPHB) \\
18.Sodium benzoate (NaBENZ)
\end{tabular}

A few of the chromatographic parameters that were varied in the initial experiments (results not shown) with a great impact on improvement of the separation of the peaks were: the temperature of the column, the flow rate and the detector parameters. Column compartment temperature of $35^{\circ} \mathrm{C}$ was shown to be optimal for the separation of all of the compounds, and the only parameter that achieved full baseline separation straight away between CAF and PHEN. The proposed flow rate was $1 \mathrm{~mL} / \mathrm{min}$, and faster flow rates didn't achieve an improvement in separation. The recorded UV spectra of the proposed analytes suggested that the detection should be performed at 215, 254 and $265 \mathrm{~nm}$, with best overall detection observed at $215 \mathrm{~nm}$ and $265 \mathrm{~nm}$ with a reference wavelength of $450 \mathrm{~nm}$. According to the expected generation of fast peaks due to the small column dimensions, a faster sampling rate of $20 \mathrm{~Hz}$ gave a far better response in the chromatogram.

\section{Method optimization}

After the initial experiments several critical resolutions between the peaks were noticed: 4AMPH/ASCAC; 4-AMPH/MALAC; EPHED/PSEEPH; CAF/PHEN; CHLIMPC/CHLPHE; CHLPHE/NaBENZ; NaBENZ/4-NITPH and 4-NITPH/DEXMETH. For complete separation of all of the compounds, the gradient was optimized using modern chemometric tools for careful and systematic planning of the experiments in order to identify the parameters of the gradient that will have the biggest impact on the separation and their optimal values.

Response surface design of experiments (DoE) was applied for systematic planning of the experiments (Acevska et al., 2015; Araujo and Brereton, 1996a, 1996b; Petkovska, 2008), which gave accurate and useful results that efficiently lead to the determination of the final gradient conditions in two sets of experiments. Since the most influential parameters of the gradient for improving separation in general are the gradient time and the gradient range as well as out from the preliminary research data, parameters chosen to be investigated in the first set of experiments were: the initial percentage of solvent $\mathrm{B}$ in the mobile phase $\left(\mathrm{W}_{0}(\% \mathrm{~B})\right)$, the gradient time $(\mathrm{tg})$ and the gradient range of solvent $\mathrm{B}(\Delta \% \mathrm{~B})$. The set of experiments was designed according to the $2^{3}$ Central Composite Face Centered (CCF) model. It consisted of seventeen experiments covering the following ranges of the chosen three experimental factors: $\mathrm{W}_{0}(\% \mathrm{~B})$ from 2 to $6 \%, \operatorname{tg}$ from $8 \mathrm{~min}$ (1st to 9 th minute of the run) to $12 \mathrm{~min}$ (1st to 13 th minute of the run) and $\triangle \% \mathrm{~B}$ from $78 \%$ (from 2 to $80 \%$ of solvent B during tg) to $94 \%$ (from 2 to $96 \%$ of solvent B during tg). The method was kept isocratic for the first minute of the run that should provide satisfactory method robustness in method transfer. The chromatographic response was evaluated based upon the resolution $\left(R_{S}\right)$ between seven of the critical peak pairs (Table 4). The impact of the chromatographic experimental factors on the separation of the method represented through the normalized coefficients of the CCF DoE is shown in Fig. 1A. The relationship between $\mathrm{R}_{\mathrm{S}}$ as chromatographic descriptor 
Table 3. Structural formulas of the compounds included in the method, their partition coefficients $(\log P)$ and dissociation constants (pKa) (PubChem Compound; DrugBank)

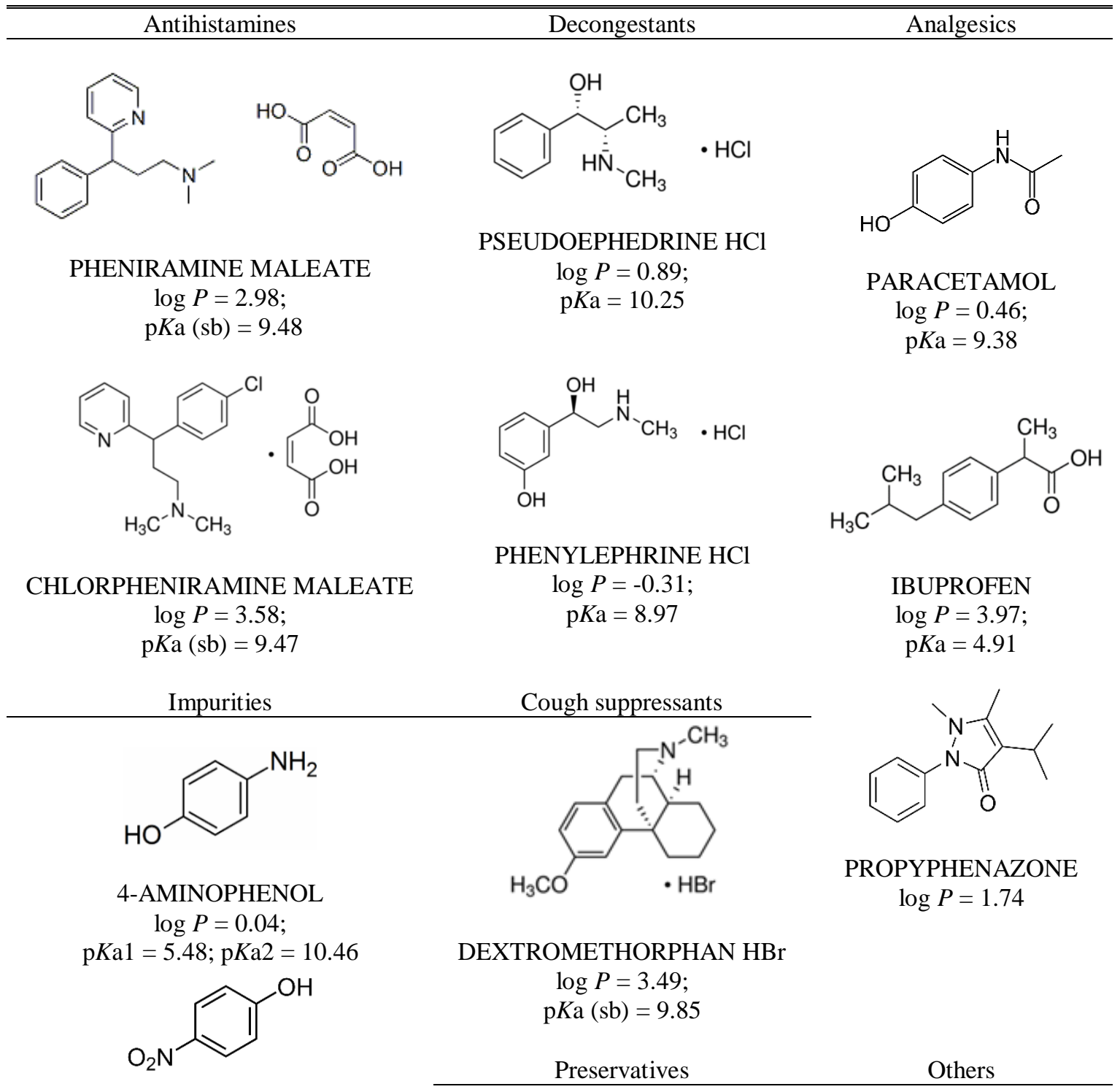

4-NITROPHENOL $\log P=1.91$

$\mathrm{pKa}=7.15$<smiles>CC(=O)Nc1ccc(Cl)cc1</smiles>

4-CHLOROACETANILIDE

$\log P=2.12$

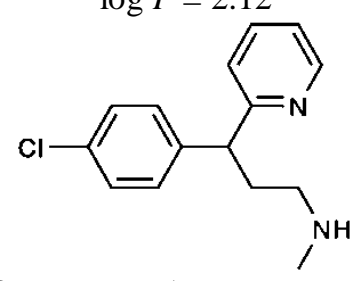

CHLORPHENIRAMINE IMPURITY<smiles>CCCOC(=O)c1ccc(O)cc1</smiles>

PROPYL PARAHYDROXY BENZOATE $\log P=3.04$ $\mathrm{p} K \mathrm{a}=8.5$<smiles>O=C1O[C@H]([C@@H](O)CO)C(O)=C1O</smiles>

ASCORBIC ACID $\log P=-1.85$; $\mathrm{p} K \mathrm{a} 1=4.17$ $\mathrm{p} K \mathrm{a} 2=11.57$<smiles>[N-][N+](=O)[O-]</smiles>

SODIUM BENZOATE

$\log P=-2.27$;

$\mathrm{p} K \mathrm{a}(\mathrm{sa})=4.08$ Counter ion 


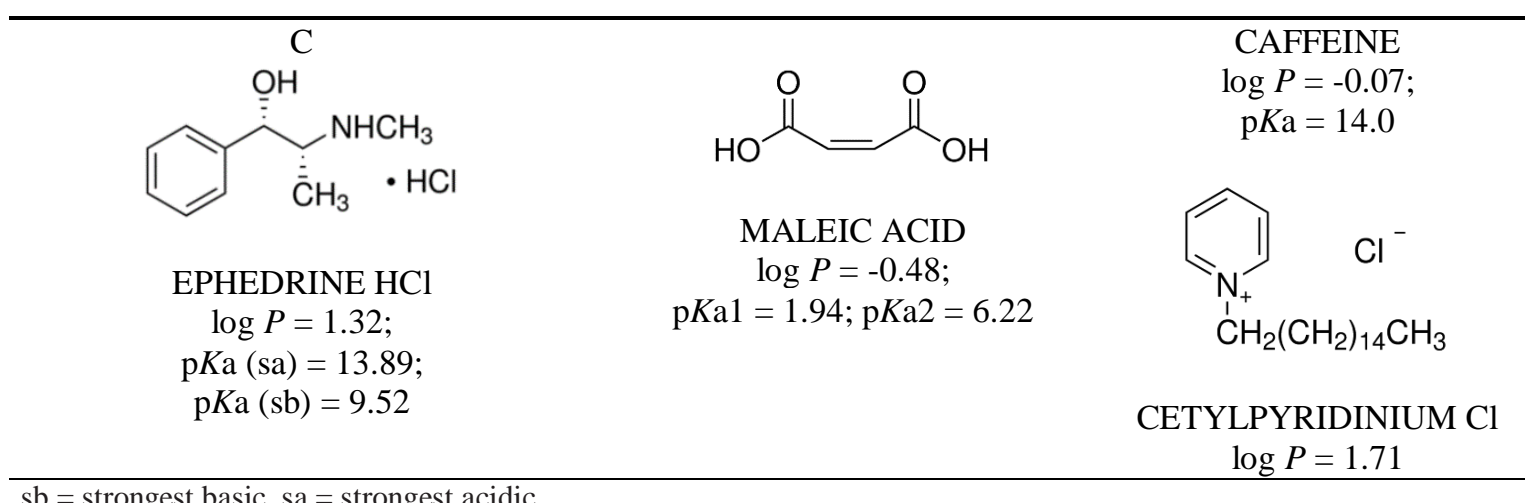

and the experimental factors over the defined experimental values is depicted in Fig. 1B with the response surface contour plot.

According to Fig. $1 \mathrm{~A}, \mathrm{~W}_{0}(\% \mathrm{~B})$ and $\operatorname{tg}$ have the biggest impact on the separation. $\mathrm{W}_{0}(\% \mathrm{~B})$ is the only parameter that influences positively the separation of 4AMPH/ASCAC, and has a lesser impact on $\mathrm{R}_{\mathrm{S}}$ of the rest of the peak pairs. $\Delta \% \mathrm{~B}$ has a less significant effect on $\mathrm{R}_{\mathrm{S}}$ than tg. Examining the influence of $\operatorname{tg}$ in Fig. $1 \mathrm{~A}$ and the nature of its relationship to $R_{S}$ in the contour plots in Fig. 1B, it is observed that in general it has opposite influence on the $R_{S}$ of the peaks from the first and the second half of the chromatogram. Increasing $\operatorname{tg}$ has a positive influence on $R_{S}$ for peaks up to around the $5^{\text {th }}$ minute of the gradient and decreasing $\operatorname{tg}$ has a positive influence on $\mathrm{R}_{\mathrm{S}}$ for peaks that appear after the 5 th minute of the gradient.

Achieving satisfactory $R_{S}$ between all of the peaks in the chromatogram according to the results of the first set of experiments would require splitting of the gradient in two steps. To achieve this, a second set of 27 experiments was acquired with $2^{4} \mathrm{CCF}$ DoE aiming toward defining

Table 4. Design of the first set of experiments according to the $2^{3} \mathrm{CCF}$ model, including three experimental factors, their chosen ranges and the results for the studied chromatographic response (resolution $\left(\mathrm{R}_{\mathrm{S}}\right)$ between seven critical peak pairs)

\begin{tabular}{ccccccccccc}
\hline $\begin{array}{c}\text { Exp } \\
\mathrm{No}\end{array}$ & $\mathrm{W}_{0}(\% \mathrm{~B})$ & $\begin{array}{c}\Delta \% \mathrm{~B} \\
{[\%]}\end{array}$ & $\begin{array}{c}\mathrm{tg} \\
{[\%]}\end{array}$ & $\mathrm{R}_{\mathrm{S}} 1$ & $\mathrm{R}_{\mathrm{S}} 2$ & $\mathrm{R}_{\mathrm{S}} 3$ & $\mathrm{R}_{\mathrm{S}} 4$ & $\mathrm{R}_{\mathrm{S}} 5$ & $\mathrm{R}_{\mathrm{S}} 6$ & $\mathrm{R}_{\mathrm{S}} 7$ \\
\hline 1 & 2 & 78 & 8 & 0.61 & 0.93 & 1.88 & 1.78 & 2.29 & 1.02 & 2.08 \\
2 & 6 & 78 & 8 & 0 & 0.91 & 3.06 & 1.87 & 1.94 & 1.20 & 2.39 \\
3 & 2 & 94 & 8 & 0.62 & 0.68 & 1.63 & 1.59 & 2.59 & 1.14 & 1.00 \\
4 & 6 & 94 & 8 & 0 & 0.93 & 2.71 & 1.64 & 2.25 & 1.28 & 1.37 \\
5 & 2 & 78 & 12 & 0.63 & 1.33 & 2.22 & 2.35 & 1.31 & 0 & 6.15 \\
6 & 6 & 78 & 12 & 0 & 0.94 & 3.69 & 224 & 0.99 & 0.84 & 4.56 \\
7 & 2 & 94 & 12 & 0.63 & 1.06 & 2.11 & 2.11 & 1.89 & 0.79 & 3.12 \\
8 & 6 & 94 & 12 & 0 & 0.93 & 3.21 & 2.16 & 1.56 & 1.14 & 3.86 \\
9 & 2 & 86 & 10 & 0.63 & 0.98 & 2.03 & 1.96 & 2.07 & 0.97 & 2.89 \\
10 & 6 & 86 & 10 & 0 & 0.96 & 3.12 & 2.03 & 1.74 & 1.19 & 3.20 \\
11 & 4 & 78 & 10 & 0 & 1.26 & 2.35 & 2.12 & 1.74 & 0.98 & 3.61 \\
12 & 4 & 94 & 10 & 0 & 1.17 & 2.13 & 1.88 & 2.12 & 1.12 & 2.41 \\
13 & 4 & 86 & 8 & 0 & 1.12 & 1.91 & 1.67 & 2.35 & 1.20 & 1.54 \\
14 & 4 & 86 & 12 & 0 & 1.29 & 2.45 & 2.24 & 1.54 & 0.81 & 3.87 \\
15 & 4 & 86 & 10 & 0 & 1.24 & 2.26 & 1.99 & 1.86 & 1.05 & 3.07 \\
16 & 4 & 86 & 10 & 0 & 1.24 & 2.26 & 1.99 & 1.87 & 1.06 & 3.08 \\
17 & 4 & 86 & 10 & 0 & 1.24 & 2.26 & 1.99 & 1.86 & 1.05 & 3.06 \\
\hline
\end{tabular}

Exp = experiment; $\mathrm{W}_{0}(\% \mathrm{~B})=$ initial percentage of solvent $\mathrm{B}$ in the mobile phase; $\Delta \% \mathrm{~B}=$ gradient range of solvent $\mathrm{B}$; $\operatorname{tg}=$ gradient time; $\mathrm{R}_{\mathrm{S}} 1=$ resolution 4 -AMPH/ASCAC; $\mathrm{R}_{\mathrm{S}} 2=$ resolution $\quad$ EPHED/PSEEPH; $\mathrm{R}_{\mathrm{S}} 3=$ resolution CAF/PHEN; $\quad \mathrm{R}_{\mathrm{S}} 4=$ resolution $\quad$ CHLIMPC/CHLPHE; $\quad \mathrm{R}_{\mathrm{S}} 5=$ resolution $\quad$ CHLPHE/NaBENZ; $\quad \mathrm{R}_{\mathrm{S}} 6=$ resolution NaBENZ/4-NITPH; $R_{S} 7$ = resolution 4-NITPH/DEXMETH

Макед. фарм. билт., 63 (2) 49 - 65 (2017) 
A
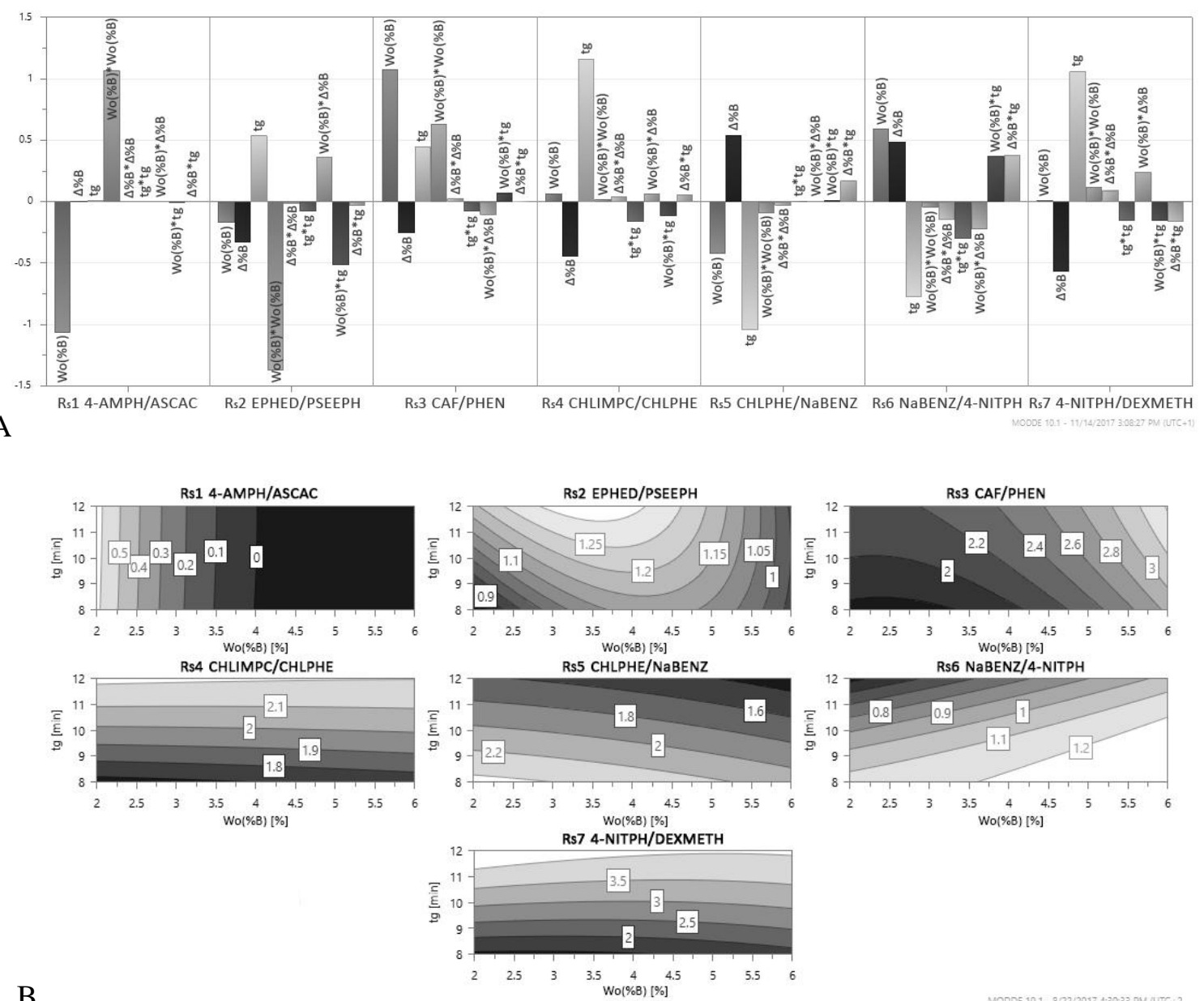

B

Fig. 1. Results from the first set of experiments using design of experiments approach ( $2^{3} \mathrm{CCF}$ DoE) during optimization of the HPLC method.

A. The impact of the studied gradient parameters: initial percentage of solvent $B$ in the mobile phase $\left(\mathrm{W}_{0}(\% \mathrm{~B})\right.$ ), gradient range of solvent $\mathrm{B}(\Delta \% \mathrm{~B})$ and gradient time $(\operatorname{tg})$ and their interactions, on the resolution $\left(\mathrm{R}_{\mathrm{S}}\right)$ between seven critical peak pairs of analytes.

B. Response surface contour plot depicting the relationship between the resolution $\left(\mathrm{R}_{\mathrm{S}}\right)$ of the seven critical peak pairs and the change in initial percentage of solvent $\mathrm{B}$ in the mobile phase $\left(\mathrm{W}_{0}(\% \mathrm{~B})\right)$ and the gradient time $(\operatorname{tg})$ over the defined experimental values (the gradient range of solvent $\mathrm{B}(\Delta \% \mathrm{~B})$ is set to $86 \%$ ).

the final look of the gradient. The defined experimental factors of the two-step gradient were: the initial percentage of solvent $\mathrm{B}$ in the mobile phase in the first step of the gradient $\left(\mathrm{W}_{0}(\% \mathrm{~B})\right)$, gradient time of the first step of the gradient $\left(\operatorname{tg}_{1}\right)$, initial percentage of solvent $B$ in the mobile phase in the second step of the gradient $\left(\mathrm{W}_{1}(\% \mathrm{~B})\right)$ and gradient time of the second step of the gradient $\left(\operatorname{tg}_{2}\right)$. The investigated experimental area of the experimental factors was: $\mathrm{W}_{0}(\% \mathrm{~B})$ from 0.1 to $2 \%, \operatorname{tg}_{1}$ from $2 \mathrm{~min}$ (1st to 3 rd minute of the run) to $4 \mathrm{~min}$ (1st to 5th minute of the run), $\mathrm{W}_{1}(\% \mathrm{~B})$ from 15 to $25 \%$ and $\operatorname{tg}_{2}$ from $8 \mathrm{~min}$ to $10 \mathrm{~min}$, depending on the time of $\operatorname{tg}_{1}$; if $\operatorname{tg}_{1}=2 \mathrm{~min}, \operatorname{tg}_{2}$ will range between the $3 \mathrm{rd}$ to 11 th minute of the run as chromatographic minimum and the 3 rd to 13th minute of the run as the chromatographic maximum; if $\operatorname{tg}_{1}=4 \mathrm{~min}, \operatorname{tg}_{2}$ will range between the 5th to 13th minute of the run as chromatographic minimum and the 5th to 15th minute of the run as the chromatographic maximum. The $R_{S}$ between nine peak pairs was used as a descriptor of the chromatographic response (Table 5). The influence of the gradient experimental factors on the separation of the method is shown in Fig. 2A represented through the normalized coefficients of the CCF DoE. The response surface shape of $R_{S}$ as a function of the experimental factors over the defined experimental values is shown in Fig. 2B with the response surface contour plot.

After analysing the chromatograms and the chemometric results (Fig. 2) it is concluded that for achieving satisfactory resolution $\left(\mathrm{R}_{\mathrm{S}} \geq 1.0\right)$ between 4 - 


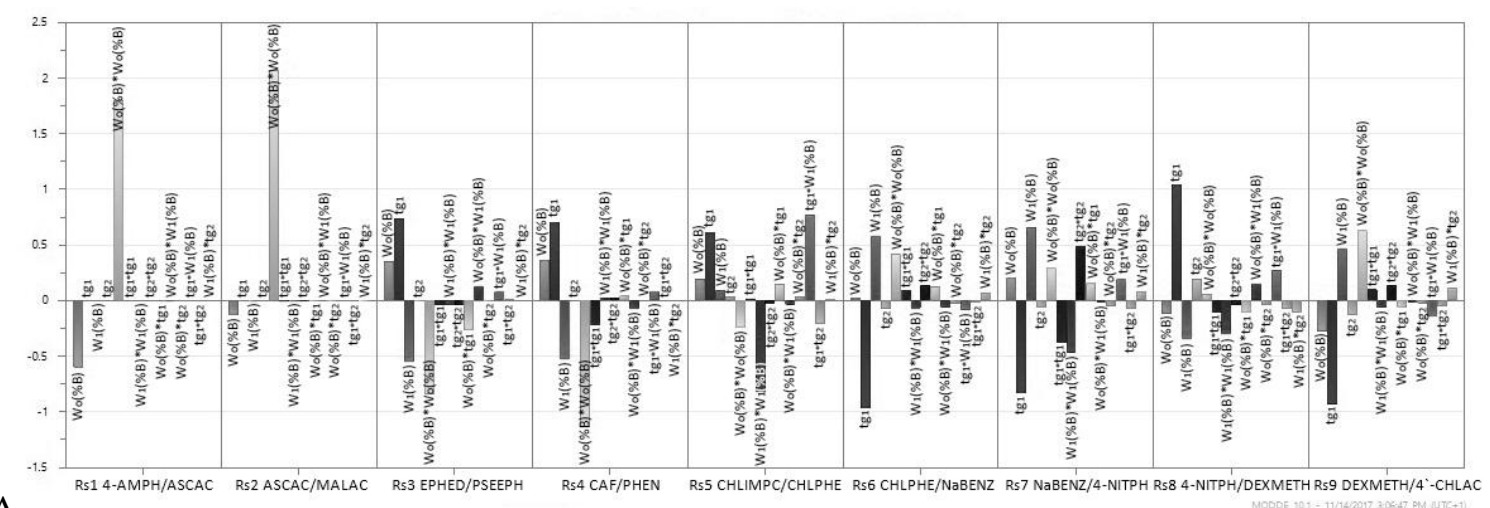

A

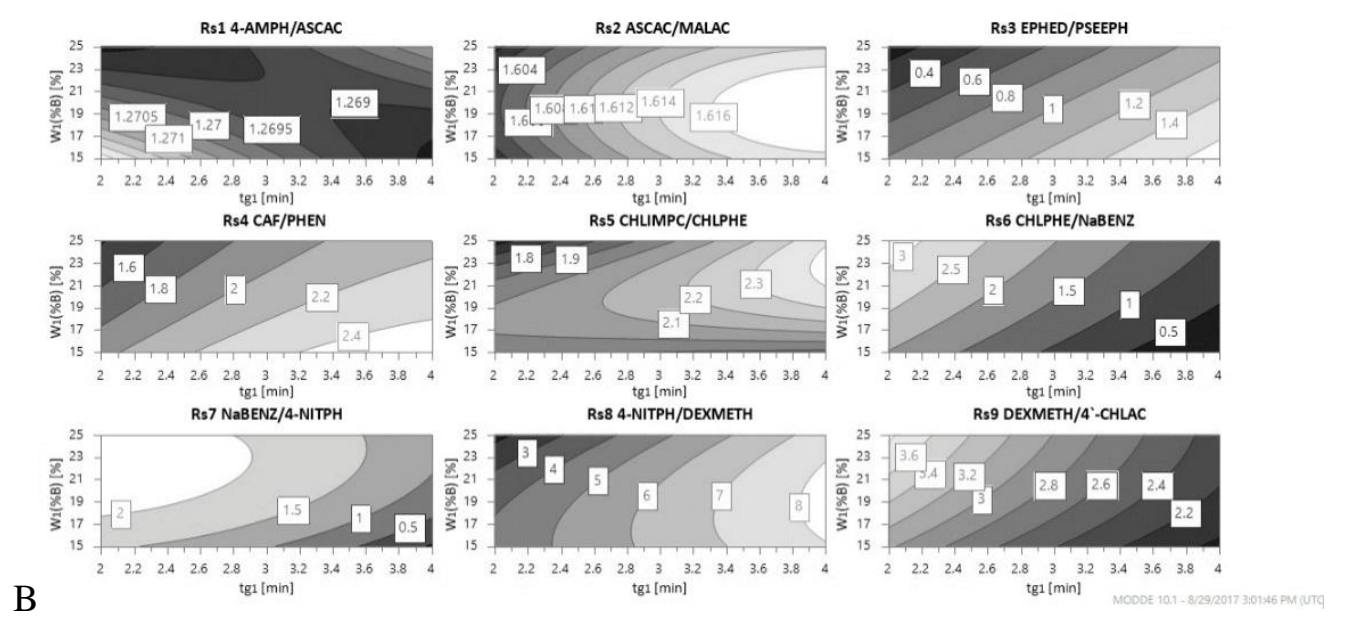

Fig. 2. Results from the second set of experiments using design of experiments approach $\left(2^{4}\right.$ CCF DoE $)$ during final optimization of the HPLC method.

A. The impact of the studied two-step gradient parameters: the initial percentage of solvent B in the mobile phase in the first step of the gradient $\left(\mathrm{W}_{0}(\% \mathrm{~B})\right)$, gradient time of the first step of the gradient $\left(\operatorname{tg}_{1}\right)$, initial percentage of solvent $\mathrm{B}$ in the mobile phase in the second step of the gradient $\left(\mathrm{W}_{1}(\% \mathrm{~B})\right)$ and gradient time of the second step of the gradient $\left(\operatorname{tg}_{2}\right)$ and their interactions, on the resolution $\left(R_{S}\right)$ between nine critical peak pairs of analytes.

B. Response surface contour plot depicting the relationship between the resolution $\left(\mathrm{R}_{\mathrm{S}}\right)$ of the nine critical peak pairs and the change in gradient time of the first step of the gradient $\left(\operatorname{tg}_{1}\right)$ and initial percentage of solvent $\mathrm{B}$ in the mobile phase in the second step of the gradient $\left(\mathrm{W}_{1}(\% \mathrm{~B})\right.$ ) over the defined experimental values (the initial percentage of solvent $B$ in the mobile phase in the first step of the gradient $\left(\mathrm{W}_{0}(\% \mathrm{~B})\right)$ is set to $0,1 \%$ and gradient time of the second step of the gradient $\left(\operatorname{tg}_{2}\right)$ is set to 8 minutes).

AMPH and ASCAC it is necessary that $\mathrm{W}_{0}(\% \mathrm{~B})$ be kept the lowest possible, that is $0.1 \%$. This factor also influences $R_{S}$ between the rest of the peaks and in opposite directions, but since it's the only factor that can separate the fore mentioned compounds it was decided to keep its value at $0.1 \%$ in the final gradient. The $\operatorname{tg}_{2}$ has almost no influence on overall $\mathrm{R}_{\mathrm{S}}$ (Fig. $2 \mathrm{~A}$ ), so its value was chosen to be at the chemometric minimum (i.e. 8 minutes). Both $\operatorname{tg}_{1}$ and $\mathrm{W}_{1}(\% \mathrm{~B})$ have an important impact on separation (Fig. 2A) opposite to one another, and also influence $R_{S}$ of the peaks from the first and the second half of the chromatogram in opposite direction. Keeping
$\mathrm{W}_{0}(\% \mathrm{~B})$ and $\operatorname{tg}_{2}$ at the constant selected values, the response surface of the influence of $\operatorname{tg}_{1}$ and $\mathrm{W}_{1}(\% \mathrm{~B})$ on $\mathrm{R}_{\mathrm{S}}$ was further investigated. Optimal values providing satisfactory resolution $\left(\mathrm{R}_{\mathrm{S}} \geq 1.0\right)$ between all of the critical peak pairs for both experimental factors were drawn from Fig. 2B, which for $\mathrm{W}_{1}(\% \mathrm{~B})$ is $15 \%$, and for $\operatorname{tg}_{1}$ is 2 min. A system suitability solution was prepared and injected using the final optimized two-step gradient, showing that complete separation $\left(R_{S} \geq 2.0\right)$ between all of the analytes was achieved. The peaks of EPHED and PSEEPH are baseline separated with a critical resolution of 1.3 (Fig. 3). 

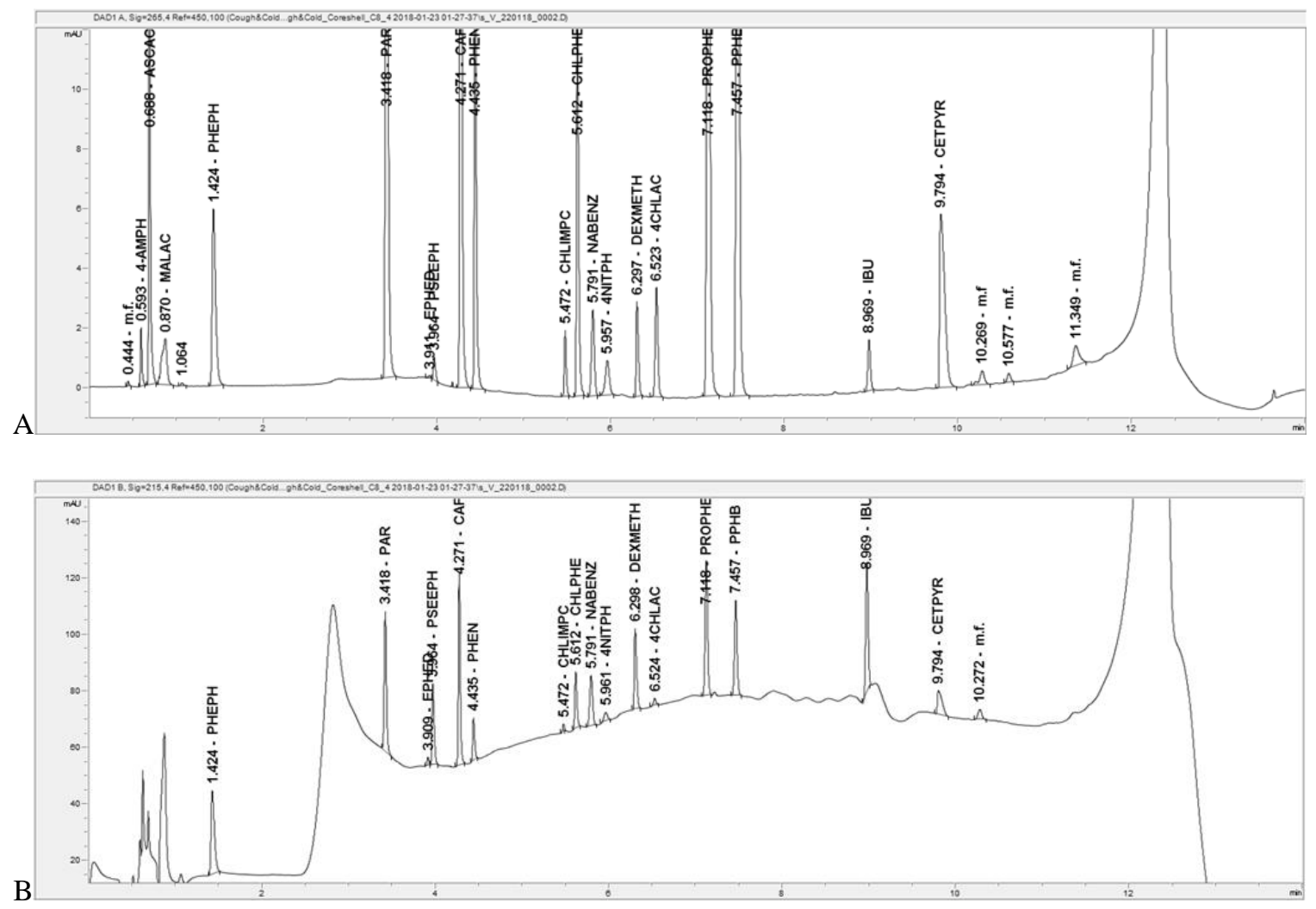

Fig. 3. Chromatogram of the system suitability solution injected with the final optimized method conditions showing adequate separation between all of the peaks of the substances included in the method.

Chromatographic conditions: Poroshell 120 EC-C $850 \mathrm{~mm} \times 4.6 \mathrm{~mm}$ i.d., $2.7 \mu \mathrm{m}$ particle size; eluents: solvent A $(0.1 \%(\mathrm{v} / \mathrm{v})$ formic acid in water) and solvent B $(0.1 \%(\mathrm{v} / \mathrm{v})$ formic acid in acetonitrile); gradient elution: $0-1$ min $0.1 \%$ solvent $\mathrm{B} ; 1-3 \mathrm{~min}$ from $0.1 \%$ to $15 \%$ solvent $\mathrm{B} ; 3-11 \mathrm{~min}$ from $15 \%$ to $90 \%$ solvent B; 11-12 min from $90 \%$ back to $0.1 \%$ solvent B and stabilisation from 12-14 min with $0.1 \%$ solvent B; flow rate, $1.0 \mathrm{~mL} / \mathrm{min}$; injection volume, $1 \mu \mathrm{L}$; column temperature, $35^{\circ} \mathrm{C}$; detection at A. $265 \mathrm{~nm}$, reference wavelength $450 \mathrm{~nm}$; bandwidth $100 \mathrm{~nm}$ (ASCAC, PAR, PHEN, PROPHE, CETPYR, PPHB, CAF, CHLPHE, 4-AMPH, 4-NITPH, 4-CHLAC, CHLIMPC) and at B. $215 \mathrm{~nm}$, reference wavelength $450 \mathrm{~nm}$; bandwidth 100 nm (PHEPH, PSEEPH, NaBENZ, DEXMETH, IBU, EPHED); sampling rate, $20 \mathrm{~Hz}$.

\section{Method validation}

The chromatographic parameters of the peaks in the chromatogram of the system suitability solution, suggesting excellent performance of the method $\left(\mathrm{R}_{\mathrm{S}} \geq 2.0\right.$, number of theoretical plates $(\mathrm{N}) \geq 5000$ tp/column, tailing factor (T) $($ USP $5 \%) \leq 2.0)$ are represented in Table 6.

The summary of the validation results showing adequate performance of the method for the parameters linearity, precision, detection and quantification limit, and accuracy of the method for the selected pharmaceutical formulations are represented in Table 7 and 8.

\section{Conclusion}

A generally applicable, reliable, fast and efficient HPLC/DAD method for simultaneous determination of the most frequently used cough and cold active substances and their impurities was developed and optimized. The compounds that the method can discriminate include eleven active substances: paracetamol, phenylephrine $\mathrm{HCl}$, caffeine, ibuprofen, ascorbic acid, propiphenazone, pheniramine maleate, chlorphenamine maleate, pseudoephedrine $\mathrm{HCl}$, dextromethorphan $\mathrm{HBr}$ and cetylpyridinium $\mathrm{Cl}$; five of their impurities: 4aminophenol, 4-nitrophenol, 4-chloroacetanilide, chlorphenamine impurity $\mathrm{C}$ and ephedrine $\mathrm{HCl}$; and two preservatives: sodium benzoate and propyl parahydroxybenzoate. All 18 compounds were successfully separated on a RP-HPLC column with superficially porous particles using gradient elution with a very simple mobile phase in 14 minutes with excellent sensitivity and resolution. Method optimization was assisted by the design of experiments approach, leading to 
Table 5. Design of the second set of experiments according to the $2^{4} \mathrm{CCF}$ model, including four experimental factors, their chosen ranges and the results for the studied chromatographic response (resolution $\left(\mathrm{R}_{\mathrm{S}}\right)$ between nine critical peak pairs)

\begin{tabular}{|c|c|c|c|c|c|c|c|c|c|c|c|c|c|}
\hline Exp No & $\begin{array}{c}\mathrm{W}_{0}(\% \mathrm{~B}) \\
{[\%]} \\
\end{array}$ & $\begin{array}{c}\operatorname{tg}_{1} \\
{[\mathrm{~min}]}\end{array}$ & $\begin{array}{c}\mathrm{W}_{1}(\% \mathrm{~B}) \\
{[\%]} \\
\end{array}$ & $\begin{array}{c}\operatorname{tg}_{2} \\
{[\mathrm{~min}]}\end{array}$ & $\mathrm{R}_{\mathrm{S}} 1$ & $\mathrm{R}_{\mathrm{S}} 2$ & $\mathrm{R}_{\mathrm{S}} 3$ & $\mathrm{R}_{\mathrm{S}} 4$ & $\mathrm{R}_{\mathrm{S}} 5$ & $\mathrm{R}_{\mathrm{S}} 6$ & $\mathrm{R}_{\mathrm{S}} 7$ & $\mathrm{R}_{\mathrm{S}} 8$ & $\mathrm{R}_{\mathrm{S}} 9$ \\
\hline 1 & 0.1 & 2 & 15 & 8 & 1.27 & 1.58 & 0.80 & 1.95 & 1.93 & 2.03 & 1.58 & 3.98 & 3.07 \\
\hline 2 & 2 & 2 & 15 & 8 & 0.64 & 1.45 & 1.25 & 2.36 & 1.92 & 1.96 & 1.69 & 3.86 & 2.77 \\
\hline 3 & 0.1 & 4 & 15 & 8 & 1.27 & 1.61 & 1.73 & 2.52 & 1.91 & 0 & 0 & 7.95 & 1.98 \\
\hline 4 & 2 & 4 & 15 & 8 & 0.64 & 1.42 & 1.75 & 3.04 & 2.10 & 0.70 & 0.87 & 6.70 & 1.57 \\
\hline 5 & 0.1 & 2 & 25 & 8 & 1.27 & 1.60 & 0 & 1.39 & 1.62 & 3.31 & 2.24 & 1.91 & 3.77 \\
\hline 6 & 2 & 2 & 25 & 8 & 0.63 & 1.43 & 0.76 & 1.65 & 1.63 & 2.90 & 2.11 & 2.28 & 3.51 \\
\hline 7 & 0.1 & 4 & 25 & 8 & 1.27 & 1.62 & 1.14 & 2.14 & 2.32 & 0.93 & 1.05 & 7.42 & 2.32 \\
\hline 8 & 2 & 4 & 25 & 8 & 0.63 & 1.42 & 1.32 & 2.50 & 2.48 & 1.19 & 1.66 & 7.33 & 1.71 \\
\hline 9 & 0.1 & 2 & 15 & 10 & 1.27 & 1.63 & 0.80 & 1.94 & 2.11 & 1.73 & 1.48 & 5.78 & 2.85 \\
\hline 10 & 2 & 2 & 15 & 10 & 0.64 & 1.42 & 1.24 & 2.37 & 2.17 & 1.77 & 1.73 & 5.22 & 2.42 \\
\hline 11 & 0.1 & 4 & 15 & 10 & 1.26 & 1.63 & 1.74 & 2.53 & 1.65 & 0 & 0 & 9.16 & 1.55 \\
\hline 12 & 2 & 4 & 15 & 10 & 0.63 & 1.43 & 1.74 & 3.05 & 1.93 & 0 & 0 & 6.97 & 1.04 \\
\hline 13 & 0.1 & 2 & 25 & 10 & 1.27 & 1.60 & 0 & 1.39 & 1.65 & 3.28 & 2.23 & 2.41 & 3.87 \\
\hline 14 & 2 & 2 & 25 & 10 & 0.63 & 1.42 & 0.74 & 1.64 & 1.68 & 2.93 & 2.21 & 2.72 & 3.51 \\
\hline 15 & 0.1 & 4 & 25 & 10 & 1.27 & 1.60 & 1.15 & 2.16 & 2.32 & 0.92 & 1.05 & 7.46 & 2.22 \\
\hline 16 & 2 & 4 & 25 & 10 & 0.64 & 1.43 & 1.34 & 2.52 & 2.48 & 1.18 & 1.67 & 7.55 & 1.64 \\
\hline 17 & 0.1 & 3 & 20 & 9 & 1.27 & 1.64 & 1.04 & 2.08 & 2.15 & 1.34 & 1.30 & 6.83 & 2.54 \\
\hline 18 & 2 & 3 & 20 & 9 & 0.63 & 1.42 & 1.31 & 2.46 & 2.31 & 1.38 & 1.66 & 6.02 & 2.10 \\
\hline 19 & 1.05 & 2 & 20 & 9 & 0 & 0 & 1.56 & 2.34 & 1.96 & 2.08 & 1.96 & 4.25 & 2.69 \\
\hline 20 & 1.05 & 4 & 20 & 9 & 0 & 0 & 1.55 & 3.16 & 2.65 & 0 & 0 & 7.97 & 1.11 \\
\hline 21 & 1.05 & 3 & 15 & 9 & 0 & 0 & 1.59 & 3.16 & 2.05 & 0 & 0 & 6.53 & 1.80 \\
\hline 22 & 1.05 & 3 & 25 & 9 & 0 & 0 & 1.52 & 2.60 & 2.08 & 1.77 & 1.84 & 4.94 & 2.45 \\
\hline 23 & 1.05 & 3 & 20 & 8 & 0 & 0 & 1.58 & 2.87 & 2.22 & 1.12 & 1.62 & 5.76 & 2.06 \\
\hline 24 & 1.05 & 3 & 20 & 10 & 0 & 0 & 1.53 & 2.89 & 2.36 & 1.05 & 1.63 & 6.71 & 1.79 \\
\hline 25 & 1.05 & 3 & 20 & 9 & 0 & 0 & 1.59 & 2.87 & 2.32 & 1.09 & 1.62 & 6.25 & 1.91 \\
\hline 26 & 1.05 & 3 & 20 & 9 & 0 & 0 & 1.55 & 2.88 & 2.31 & 1.06 & 1.63 & 6.33 & 1.93 \\
\hline 27 & 1.05 & 3 & 20 & 9 & 0 & 0 & 1.37 & 2.93 & 2.29 & 1.02 & 1.59 & 6.23 & 1.87 \\
\hline
\end{tabular}

Exp = experiment; $\mathrm{W}_{0}(\% \mathrm{~B})=$ initial percentage of solvent $\mathrm{B}$ in the mobile phase in the first step of the gradient; $\operatorname{tg}_{1}=$ gradient time of the first step of the gradient; $\mathrm{W}_{1}(\% \mathrm{~B})=$ initial percentage of solvent $\mathrm{B}$ in the mobile phase in the second step of the gradient; $\operatorname{tg}_{2}=$ gradient time of the second step of the gradient; $\mathrm{R}_{\mathrm{S}} 1=$ resolution 4-AMPH/ASCAC; $\mathrm{R}_{\mathrm{S}} 2$ = resolution ASCAC/MALAC; $\mathrm{R}_{\mathrm{S}} 3=$ resolution EPHED/PSEEPH; $\mathrm{R}_{\mathrm{S}} 4=$ resolution $\mathrm{CAF} / \mathrm{PHEN} ; \mathrm{R}_{\mathrm{S}} 5=$ resolution CHLIMPC/CHLPHE; $\mathrm{R}_{\mathrm{S}} 6$ = resolution CHLPHE/NaBENZ; $\mathrm{R}_{\mathrm{S}} 7=$ resolution NaBENZ/4-NITPH; $\mathrm{R}_{\mathrm{S}} 8=$ resolution 4NITPH/DEXMETH; $\mathrm{R}_{\mathrm{S}} 9$ = resolution DEXMETH/4-CHLAC

a faster and accurate conclusion of the final method conditions. The proposed method has been validated and proved to be suitable for the simultaneous qualitative and quantitative determination of the selected compounds in different cough and cold dosage forms. The resolution power of the method for the big number of included compounds can serve for screening and quantifying components as is expected in comprehensive market surveillance studies where completely different formulations of similar medicinal product types are expected to be controlled for quality.

The results of this study revealed further possibilities of the applied approach (combination of the proposed simple mobile phase at gradient elution, core-shell technology, and the design of experiment approach for optimization) for resolving compounds with broad range of polarities. Therefore, it is proposed that this methodology can be used as a platform and a common 
starting point for an easy development and optimization of methods that encompass a large number of compounds, which could be exploited as magic bullet screening methods.

Table 6. Peak performance parameters of the chromatogram of the system suitability solution

\begin{tabular}{llcccccccc}
\hline \multirow{2}{*}{$\#$} & \multirow{2}{*}{ Substance } & \multicolumn{2}{c}{ RT (minutes) } & \multicolumn{2}{c}{ Resolution } & \multicolumn{2}{c}{$\mathrm{N}$ (tp/column) } & \multicolumn{2}{c}{ T (USP 5\%) } \\
& & $265 \mathrm{~nm}$ & $215 \mathrm{~nm}$ & $265 \mathrm{~nm}$ & $215 \mathrm{~nm}$ & $265 \mathrm{~nm}$ & $215 \mathrm{~nm}$ & $265 \mathrm{~nm}$ & $215 \mathrm{~nm}$ \\
\hline 1 & 4-AMPH & 0.593 & - & - & - & 6197 & - & 1.83 & - \\
2 & ASCAC & 0.688 & - & 3.17 & - & 8453 & - & 1.55 & - \\
3 & MALAC & 0.870 & - & 2.42 & - & - & - & - & - \\
4 & PHEPH & 1.424 & 1.424 & 5.74 & 8.04 & 6343 & 6470 & 1.67 & 1.87 \\
5 & PAR & 3.418 & 3.418 & 33.99 & 34.29 & 89710 & 91022 & 1.19 & 1.08 \\
6 & EPHED & 3.911 & 3.909 & 11.15 & 11.54 & 135499 & 155481 & 0.88 & 1.27 \\
7 & PSEEPH & 3.964 & 3.964 & 1.21 & 1.25 & 118676 & 106385 & 1.32 & 1.63 \\
8 & CAF & 4.271 & 4.271 & 7.28 & 7.04 & 201847 & 199584 & 1.30 & 1.32 \\
9 & PHEN & 4.435 & 4.435 & 4.08 & 4.04 & 174279 & 170521 & 1.58 & 1.93 \\
10 & CHLIMPC & 5.472 & 5.472 & 25.21 & 25.85 & 304715 & 346698 & 1.26 & 1.23 \\
\hline 11 & CHLPHE & 5.612 & 5.612 & 3.35 & 3.39 & 261474 & 245387 & 1.49 & 2.03 \\
12 & NaBENZ & 5.791 & 5.791 & 3.39 & 3.33 & 142455 & 141365 & 1.08 & 1.11 \\
13 & 4-NITPH & 5.957 & 5.961 & 2.31 & 2.39 & 84138 & 87238 & 1.00 & 1.39 \\
14 & DEXMETH & 6.297 & 6.298 & 5.22 & 5.18 & 273666 & 263242 & 1.75 & 1.75 \\
15 & 4-CHLAC & 6.523 & 6.524 & 4.39 & 4.35 & 231009 & 227102 & 1.10 & 1.67 \\
16 & PROPHE & 7.118 & 7.118 & 11.27 & 11.17 & 309260 & 306191 & 1.15 & 1.13 \\
17 & PPHB & 7.457 & 7.457 & 6.44 & 6.37 & 305919 & 296729 & 1.12 & 1.10 \\
18 & IBU & 8.969 & 8.969 & 27.90 & 27.69 & 436719 & 436719 & 1.22 & 1.33 \\
19 & CETPYR & 9.794 & 9.794 & 9.97 & 10.31 & 124703 & 137872 & 2.83 & 2.24 \\
\hline
\end{tabular}

$\mathrm{RT}=$ retention time; $\mathrm{N}=$ number of theoretical plates; $\mathrm{tp}=$ theoretical plates; $\mathrm{T}(\mathrm{USP} 5 \%)=$ USP tailing factor at $5 \%$ of peak height

\section{References}

Acevska, J., Stefkov, G., Dimitrovska, A., 2015. Study on chromatographic behavior of opium poppy alkaloids: Chemometric approach for development, optimization and validation of different chromatographic methods. Lambert Academic Publishing, Saarbrücken.

Acheampong, A., Owusu Gyasi, W., Darko, G., Apau, J., Addai-Arhin, S., 2016. Validated RP-HPLC method for simultaneous determination and quantification of chlorpheniramine maleate, paracetamol and caffeine in tablet formulation. SpringerPlus. 5, 625. Available at: https://doi.org/10.1186/s40064-016-2241-2.

Araujo, P.W., Brereton, R.G., 1996a. Experimental design I. Screening. Trends Anal. Chem. 15(1), 26-31. Available at: https://doi.org/10.1016/0165-9936(96)88034-4.

Araujo, P.W., Brereton, R.G., 1996b. Experimental design II. Optimization. Trends Anal. Chem. 15(2), 63-70. Available at: https://doi.org/10.1016/0165-9936(96)80762-X.

Barwick, V., 2003. Preparation of calibration curves: A guide to best practice. LGC.

Borkar, N., Sawant, S., 2011. Review of simultaneous determination of analytes by high performance liquid chromatography (HLPC) in multicomponent cough and cold oral drug products. Int. J. PharmTech. Res. 3(3), 1339-1345.

Borkar, N., Sawant, S., 2015. Validation of high performance liquid chromatographic method for the simultaneous determination of common cough and cold ingredients in multicomponent oral drug products. Int. J. Pharm. Chem. Biol. Sci. 5, 47-62.

ChromAcademy, a service of LCGC, e-learning for the analytical chemistry community. The theory of HPLC: Gradient HPLC. Crawford Scientific. Available at: https://www.chromacademy.com/lms/sco8/Theory_Of_H PLC_Gradient_HPLC.pdf.

Dewani, A.P., Shelke, P.G., Bakal, R.L., Jaybhaye, S.S., Chandewar, A.V., Patra, S., 2014. Gradient HPLCDAD determination of paracetamol, phenylephrine hydrochloride, cetirizine in tablet formulation. Drug Res. 64, 251-256. Available at: https://doi.org/10.1055/s-00331357191.

Dewani, A.P., Patra, S., 2015. A single HPLC-DAD method for simultaneous analysis of paracetamol, phenyephrine, caffeine and levocetirizine in bulk powder and tablet formulation: Application to in vitro dissolution studies. J. Chil. Chem. Soc. 60(4), 2734-2739. Available at: http://dx.doi.org/10.4067/S0717-97072015000400019.

Maced. pharm. bull., 63 (2) 49 - 65 (2017) 
Table 7. Results for method validation parameters

\begin{tabular}{|c|c|c|c|c|c|c|c|c|c|}
\hline Substance & & & arity $^{\mathrm{a}}$ & & System pr & ision (RSD/\% & & $\mathrm{LOD}^{\mathrm{c}}$ & $\mathrm{LOQ}^{\mathrm{c}}$ \\
\hline $\begin{array}{l}\text { Active substances and } \\
\text { preservatives }\end{array}$ & Range & $\mathrm{R}^{2}$ & Line Equation & $\begin{array}{c}5 \mu \mathrm{g} / \mathrm{mL} \\
(\mathrm{n}=3)\end{array}$ & $\begin{array}{c}25 \mu \mathrm{g} / \mathrm{mL} \\
(\mathrm{n}=6)\end{array}$ & $\begin{array}{c}100 \mu \mathrm{g} / \mathrm{mL} \\
(\mathrm{n}=6)\end{array}$ & $\begin{array}{c}300 \mu \mathrm{g} / \mathrm{mL} \\
(\mathrm{n}=3)\end{array}$ & & \\
\hline ASCAC (265 nm) & $\begin{array}{l}5-300 \\
\mu \mathrm{g} / \mathrm{mL} \\
5-300\end{array}$ & 0.9996 & $y=0.868 x+0.3004$ & 0.40 & 0.12 & 0.37 & 0.23 & - & - \\
\hline PHEPH (215 nm) & $\begin{array}{l}\mu \mathrm{g} / \mathrm{mL} \\
5-300\end{array}$ & 0.9992 & $y=1.555 x+0.3626$ & 1.08 & 0.33 & 0.45 & 0.26 & - & - \\
\hline PAR (265 nm) & $\begin{array}{l}\mu \mathrm{g} / \mathrm{mL} \\
5-300\end{array}$ & 0.9992 & $y=1.4614 x-0.2976$ & 0.53 & 0.14 & 0.06 & 0.10 & - & - \\
\hline PSEEPH (215 nm) & $\begin{array}{l}\mu \mathrm{g} / \mathrm{mL} \\
5-300\end{array}$ & 0.9994 & $y=0.999 x+0.983$ & 0.34 & 0.86 & 0.32 & 0.80 & - & - \\
\hline PHEN (265 nm) & $\begin{array}{l}\mu \mathrm{g} / \mathrm{mL} \\
5-300\end{array}$ & 0.9994 & $y=0.9711 x+0.9573$ & 0.81 & 0.19 & 0.26 & 0.20 & - & - \\
\hline NaBENZ (215 nm) & $\begin{array}{l}\mu \mathrm{g} / \mathrm{mL} \\
5-300\end{array}$ & 0.9992 & $y=1.6621 x+0.3143$ & 1.04 & 1.10 & 0.61 & 0.30 & - & - \\
\hline DEXMET (215 nm) & $\mu \mathrm{g} / \mathrm{mL}$ & 0.9995 & $\mathrm{y}=1.0835 \mathrm{x}-0.1364$ & 0.73 & 0.97 & 0.76 & 0.30 & - & - \\
\hline PROPHE (265 nm) & $\begin{array}{l}5-300 \\
\mu \mathrm{g} / \mathrm{mL} \\
5-300\end{array}$ & 0.9993 & $y=1.8928 x+1.2099$ & 0.41 & 0.37 & 0.09 & 0.21 & - & - \\
\hline IBU (215 nm) & $\begin{array}{l}\mu \mathrm{g} / \mathrm{mL} \\
5-300\end{array}$ & 0.9989 & $y=2.0005 x-5.8093$ & 0.84 & 1.05 & 1.02 & 0.04 & - & - \\
\hline CETPYR (265 nm) & $\begin{array}{l}\mu \mathrm{g} / \mathrm{mL} \\
5-300\end{array}$ & 0.9994 & $y=0.4913 x-0.9499$ & 1.56 & 0.23 & 0.24 & 0.25 & - & - \\
\hline CAF (265 nm) & $\begin{array}{l}\mu \mathrm{g} / \mathrm{mL} \\
5-300\end{array}$ & 0.9995 & $y=2.2199 x-2.0469$ & 0.42 & 0.43 & 0.16 & 0.05 & - & - \\
\hline CHLPHE (265 nm) & $\begin{array}{l}\mu \mathrm{g} / \mathrm{mL} \\
5-300\end{array}$ & 0.9996 & $y=0.903 x+0.0322$ & 0.69 & 0.25 & 0.14 & 0.20 & - & - \\
\hline $\begin{array}{r}\text { PPHB }(265 \mathrm{~nm}) \\
\text { Impurities }\end{array}$ & $\mu \mathrm{g} / \mathrm{mL}$ & 0.9993 & $y=3.616 x+3.9602$ & $\begin{array}{c}0.23 \\
\text { LOD }^{c} \\
(n=10)\end{array}$ & $\begin{array}{c}0.39 \\
\text { LOQ } \\
(n=10)\end{array}$ & $\begin{array}{c}0.14 \\
1 \mu \mathrm{g} / \mathrm{mL} \\
(\mathrm{n}=10)\end{array}$ & $\begin{array}{c}0.18 \\
20 \mu \mathrm{g} / \mathrm{mL} \\
(\mathrm{n}=3)\end{array}$ & - & - \\
\hline 4-AMPH (265 nm) & $\begin{array}{l}0.1-20 \\
\mu \mathrm{g} / \mathrm{mL} \\
0.5-20\end{array}$ & 0.9994 & $y=0.5311 x-0.0742$ & 16.65 & 7.70 & 2.99 & 0.07 & 0.1 & 0.2 \\
\hline 4-NITPH (265 nm) & $\begin{array}{c}\mu \mathrm{g} / \mathrm{mL} \\
0.1-20\end{array}$ & 0.9991 & $y=0.6861 x+0.1821$ & 2.52 & 2.52 & 2.34 & 0.38 & 0.5 & 0.5 \\
\hline 4-CHLAC (265 nm) & $\mu \mathrm{g} / \mathrm{mL}$ & 0.9998 & $y=1.5822 x+0.0262$ & 10.18 & 3.41 & 1.48 & 0.05 & 0.1 & 0.2 \\
\hline
\end{tabular}




\begin{tabular}{|c|c|c|c|c|c|c|c|c|c|}
\hline CHLIMPC (265 nm) & $\begin{array}{c}0.2-20 \\
\mu \mathrm{g} / \mathrm{mL} \\
0.5-20\end{array}$ & 0.9994 & $y=0.9537 x-0.0823$ & 20.44 & 5.94 & 2.25 & 0.17 & 0.2 & 0.5 \\
\hline EPHED (215 nm) & $\mu \mathrm{g} / \mathrm{mL}$ & 0.9982 & $\mathrm{y}=1.0459 \mathrm{x}-0.2795$ & 12.92 & 8.88 & 4.79 & 2.58 & 0.5 & 0.75 \\
\hline
\end{tabular}

${ }^{a}$ Assessed through 11 concentration levels in the range of $5-300 \mu \mathrm{g} / \mathrm{mL}$ for the active substances (AS) and the preservatives (PRE), and through 14 concentration levels in the range of

$0.1-20 \mu \mathrm{g} / \mathrm{mL}$ for the impurities (IMP). Linear relationship was obtained between the peak area and the corresponding concentration ( $\mathrm{R}^{2} \geq 0.997$ for $A S$ and $P R E$, and $\mathrm{R}^{2} \geq 0.98$ for IMP).

${ }^{\mathrm{b}}$ System precision for the AS and the PRE was assessed by replicate injections of standard solutions at $5 \mu \mathrm{g} / \mathrm{mL}, 25 \mu \mathrm{g} / \mathrm{mL}, 100 \mu \mathrm{g} / \mathrm{mL}$ and $300 \mu \mathrm{g} / \mathrm{mL}$. The obtained values for the RSD of the peak areas showed adequate system precision (RSD $\leq 2.0 \%$ ). For the IMP, system precision was assessed by replicate injections of standard solutions at LOQ, $1 \mu \mathrm{g} / \mathrm{mL}$ and $20 \mu \mathrm{g} / \mathrm{mL}$ and the method was confirmed to be precise (RSD $\leq 5.0 \%$ and $\mathrm{RSD} \leq 10.0 \%$ at LOQ).

${ }^{\mathbf{c}}$ LOD and LOQ for the IMP were predicted based on the standard deviation of the response and the slope from a calibration curve, examining the response of a set of solutions at low concentration levels, from $0.1-2.0 \mu \mathrm{g} / \mathrm{mL}$. Experimental check was done to confirm the calculated values, evaluating injection repeatability (RSD (n=10) $\leq 33.0 \%$ at LOD; RSD $(\mathrm{n}=10) \leq 10.0 \%$ at LOQ $)$. 
Table 8. Results for method validation parameters

\begin{tabular}{|c|c|c|c|c|}
\hline Substance & & Accuracy $^{\mathrm{a}}$ & & $\begin{array}{l}\text { Method precision } \\
(\mathrm{RSD} / \%)^{\mathrm{b}}\end{array}$ \\
\hline $\begin{array}{l}\text { OTC formulation } 1 \\
\text { (syrup) }\end{array}$ & $\begin{array}{c}\text { Recovery }(\%, \mathrm{n}=3) \\
\text { on } 50 \% \text { of } \mathrm{c}_{\mathrm{w}}\end{array}$ & $\begin{array}{c}\text { Recovery }(\%, \mathrm{n}=3) \\
\text { on } 100 \% \text { of } \mathrm{c}_{\mathrm{w}}\end{array}$ & $\begin{array}{c}\text { Recovery }(\%, \mathrm{n}=3) \\
\text { on } 150 \% \text { of } \mathrm{c}_{\mathrm{w}}\end{array}$ & $\begin{array}{c}\text { at } 100 \% \text { of } \mathrm{c}_{\mathrm{w}} \\
(\mathrm{n}=6)\end{array}$ \\
\hline $\begin{array}{l}\text { PAR }(265 \mathrm{~nm}) \\
\left(\mathrm{c}_{\mathrm{w}}=100 \mu \mathrm{g} / \mathrm{mL}\right)\end{array}$ & $99.9 \pm 1.4$ & $101.0 \pm 0.9$ & $99.5 \pm 1.1$ & 1.07 \\
\hline $\begin{array}{l}\text { DEXMETH }(215 \mathrm{~nm}) \\
\left(\mathrm{c}_{\mathrm{w}}=50 \mu \mathrm{g} / \mathrm{mL}\right)\end{array}$ & $99.8 \pm 1.5$ & $99.9 \pm 1.7$ & $101.2 \pm 1.1$ & 0.88 \\
\hline $\begin{array}{l}\text { CHLPHE }(265 \mathrm{~nm}) \\
\left(\mathrm{c}_{\mathrm{w}}=10 \mu \mathrm{g} / \mathrm{mL}\right)\end{array}$ & $101.1 \pm 2.2$ & $101.7 \pm 0.9$ & $100.4 \pm 0.7$ & 1.45 \\
\hline $\begin{array}{l}\text { PSEEPH }(215 \mathrm{~nm}) \\
\left(\mathrm{c}_{\mathrm{w}}=150 \mu \mathrm{g} / \mathrm{mL}\right)\end{array}$ & $100.3 \pm 0.6$ & $101.5 \pm 0.8$ & $101.6 \pm 0.6$ & 0.96 \\
\hline \multicolumn{5}{|l|}{$\begin{array}{l}\text { OTC formulation } 2 \\
\text { (powder for oral solution) }\end{array}$} \\
\hline $\begin{array}{l}\text { PAR }(265 \mathrm{~nm}) \\
\left(\mathrm{c}_{\mathrm{w}}=200 \mu \mathrm{g} / \mathrm{mL}\right)\end{array}$ & $101.37 \pm 0.6$ & $101.00 \pm 0.8$ & $98.07 \pm 0.02$ & 1.87 \\
\hline $\begin{array}{l}\text { PHEPH }(215 \mathrm{~nm}) \\
\left(c_{\mathrm{w}}=50 \mu \mathrm{g} / \mathrm{mL}\right)\end{array}$ & $100.21 \pm 2.2$ & $100.15 \pm 2.5$ & $101.73 \pm 1.1$ & 1.14 \\
\hline \multicolumn{5}{|l|}{$\begin{array}{l}\text { OTC formulation } 3 \\
\text { (film-coated tablet) }\end{array}$} \\
\hline $\begin{array}{l}\text { IBU }(215 \mathrm{~nm}) \\
\left(\mathrm{c}_{\mathrm{w}}=40 \mu \mathrm{g} / \mathrm{mL}\right)\end{array}$ & $101.78 \pm 3.1$ & $98.80 \pm 2.9$ & $101.58 \pm 1.8$ & 1.21 \\
\hline $\begin{array}{l}\text { PAR }(265 \mathrm{~nm}) \\
\left(c_{\mathrm{w}}=100 \mu \mathrm{g} / \mathrm{mL}\right)\end{array}$ & $101.90 \pm 0.9$ & $100.22 \pm 1.9$ & $101.63 \pm 1.7$ & 0.77 \\
\hline
\end{tabular}

$\mathrm{c}_{\mathrm{w}}=$ working concentration; $\mathrm{n}=$ number of determinations; $\mathrm{RSD}=$ relative standard deviation

${ }^{a}$ The accuracy of the method was validated using the method of standard additions. The calculated recovery values along with their confidence interval $(\mathrm{P}=95 \%)$ confirm the method accuracy $(100 \pm 2 \%)$.

${ }^{\mathrm{b}}$ Method precision was assessed by preparing six sample solutions at $100 \%$ of the working concentration. The calculated RSD for the peak areas shows adequate method precision (RSD $\leq 2.0 \%)$. 
Dewani, A.P., Dabhade S.M., Bakal, R.L., Gadewar, C.K., Chandewar, A.V., Patra, S., 2015. Development and validation of a novel RP-HPLC method for simultaneous determination of paracetamol, phenylephrine hydrochloride, caffeine, cetirizine and nimesulide in tablet formulation. Arab. J. Chem. 8, 591-598. Available at: https://doi.org/10.1016/j.arabjc.2013.09.040.

Dolan, J.W., Snyder, L.R., 2000. Essential guides to method development in liquid chromatography. Appendix 2. Academic Press. 4626-4636.

DrugBank [online] Available at: https://www.drugbank.ca/. Last accessed: July 23, 2018.

Food and Drug Administration, Center for Drug Evaluation and Research, (FDA, CDER), 1994. Reviewer guidance: Validation of chromatographic methods. FDA, CDER, Rockville.

Food and Drug Administration, Center for Drug Evaluation and Research, Center for Biologics Evaluation and Research (FDA, CDER, CBER), 2015. Analytical procedures and methods validation for drugs and biologics: Guidance for industry. FDA, CDER, CBER, Silver Spring.

Grumbach, E.S., Diehl, D.M., Mazzeo, J.R., 2007. Quantitation of over-the-counter cold medicine formulations using UPLC technology (Application Note). Waters Corporation, Milford.

Hasan, N., Chaiharn, M., Toor, U.A., Mirani, Z.A., Sajjad, G., Sher, N., Aziz, M., Siddiqui, F.A., 2016. Development, validation and application of RP-HPLC method: Simultaneous determination of antihistamine and preservatives with paracetamol in liquid formulations and human serum. Open Med. Chem. J. 10, 33-43. Available at: https://doi.org/10.2174/1874104501610010033.

Hayes, R., Ahmed, A., Edge, T., Zhang, H., 2014. Core-shell particles: Preparation, fundamentals and applications in high performance liquid chromatography. J. Chromatogr. A 1357, 36-52. Available at: https://doi.org/10.1016/j.chroma.2014.05.010.

Ibrahim, F., El-Enany, N., El-Shaheny, R.N., Mikhail, I.E., 2015. Development and validation of a new HPLC method for the simultaneous determination of paracetamol, ascorbic acid, and pseudoephedrine $\mathrm{HCl}$ in their coformulated tablets. Application to in vitro dissolution testing. Anal. Sci. 31, 943-947. Available at: https://doi.org/10.2116/analsci.31.943.

International Conference on Harmonisation (ICH) of Technical Requirements for Registration of Pharmaceuticals for Human Use, 2005. ICH Harmonised Tripartite Guideline: Validation of analytical procedures: Text and methodology Q2(R1). ICH, Geneva.

Little, T.A., 2015. Method validation essentials, limit of blank, limit of detection, and limit of quantitation. BioPharm Int. 28(4), 48-51.

Marín, A., García, E.,García, A., Barbas, C., 2002. Validation of a HPLC quantification of acetaminophen, phenylephrine and chlorpheniramine in pharmaceutical formulations: capsules and sachets. J. Pharm. Biomed. Anal. 29, 701714. Available at: https://doi.org/10.1016/S0731-
7085(02)00124-3.

Palabiyik, I.M., Onur, F., 2010. Multivariate optimization and validation of a capillary electrophoresis method for the simultaneous determination of dextromethorphan hydrobromur, phenylephrine hydrochloride, paracetamol and chlorpheniramine maleate in a pharmaceutical preparation using response surface methodology. Anal. Sci. 26, 853-859. Available at: https://doi.org/10.2116/analsci.26.853.

Pedjie, N., 2011. Analysis of drug substances in common cold medicines with the PerkinElmer Flexar FX-15 system equipped with a PDA detector (Application Note: UHPLC). PerkinElmer, Inc., Waltham.

Petkovska, R., 2008. Chemometric approach for experimental designing of HPLC methods for determination of impurities in therapeutically active substances. University "Ss Cyril and Methodius", Skopje.

Phenomenex, Inc., 2009. Kinetex ultra-high performance on any LC system. Phenomenex, Inc.

PubChem Compound [online] Available at: https://www.ncbi.nlm.nih.gov/pccompound. Last accessed: July 23, 2018.

Sehrawat, R., Khatak, M., Maithani, M., Khatak, S., 2013. Simultaneous determination of chlorpheniramine maleate, paracetamol and phenylephrine hydrochloride in tablet dosage form by high performance liquid chromatography. Int. J. Drug Dev. Res. 5, 258-263.

Shabir, G.A., 2004. Step-by-step analytical methods validation and protocol in the quality system compliance industry. J. Validation Technol. 10(4), 314-324.

Snyder, L.R., Kirkland J.J., Dolan, J.W., 2010. Introduction to Modern Liquid Chromatography, third ed. John Wiley \& Sons, Inc., Hoboken, New Jersey.

Trass, M., Lomas, S., 2015. Cold medicine API screen using a Kinetex ${ }^{\circledR}$ EVO $\mathrm{C} 18$ core-shell LC column (Application Note). Phenomenex, Inc.

U.S. Pharmacopoeia 40-National Formulary 35 (USP 40-NF 35), 2017. <1225> Validation of compendial procedures. United States Pharmacopeial Convention, Rockville.

Van Schoor, J., 2013. Colds, flu and coughing: A review of overthe-counter cold and flu medicines. S. Afr. Fam. Pract. 55(4), 334-336.

Waters Corporation, 2014. Cortecs Columns Applications Notebook. Waters Corporation, Milford.

Xuan, X., Huang, L., Pan, X., Li, N., 2013. Simultaneous determination of five cold medicine ingredients in paracetamol triprolidine hydrochloride and pseudoephedrine hydrochloride tablets by $\mathrm{pH} /$ organic solvent double-gradient high performance liquid chromatography. Chin. J. Chromatogr. 31, 133-138. Available at: https://doi.org/10.3724/sp.j.1123.2012.09023.

Yehia, A.M., Essam, H.M., 2016. Development and validation of a generic high-performance liquid chromatography method for the simultaneous separation and determination of six cough ingredients: Robustness study on core-shell particles. J. Sep. Sci. 39, 3357-3367. Available at: https://doi.org/10.1002/jssc.201600438. 


\title{
Развој и оптимизација на генерички HPLC метод за истовремено определување на најчесто застапените супстанции во мулти-компонентните перорални лекови за настинка, грип и кашлица со примена на хемометрија
}

\author{
Марија Зафирова ${ }^{1 *}$, Јелена Ацевска ${ }^{2}$, Лилјана Угринова ${ }^{1}$, \\ Габриела Петровска-Димитриевска ${ }^{1}$, Васил Карчев ${ }^{1}$, Наталија Наков ${ }^{2}$, \\ Катерина Брезовска ${ }^{2}$, Анета Димитровска ${ }^{2}$, Руменка Петковска $^{2}$, \\ Лилјана Анастасова ${ }^{2}$, Јасмина Тониќ-Рибарска ${ }^{2}$, Ана Поцева Пановска $^{2}$, \\ Зоран Кавраковски ${ }^{2}$, Сузана Трајковиќ-Јолевска ${ }^{2}$ \\ ${ }^{1}$ Центар за испитување и контрола на лекови, Фармацевтски факултет, \\ Универзитет „,Св.Кирил и Методиј”, Мајка Тереза 47, 1000 Скопје, \\ Република Македонија \\ ${ }^{2}$ Институт за применета хемија и фармацевтски анализи, Фармацевтски факултет, \\ Универзитет „Св.Кирил и Методиј”, Мајка Тереза 47, 1000 Скопје, \\ Република Македонија
}

Клучни зборови: активни супстанции и онечистувања во лекови за настинка, грип и кашлица, HPLC/DAD, површинско-порозни честички, core-shell честички, хемометрија, дизајн на експерименти

Целта на овој труд е развој на единствен, генерално апликативен метод на високоефикасна течна хроматографија во спрега со детектор со диодна решетка (HPLC/DAD), наменет за истовремено определување на најчесто застапените активни супстанции и нивните онечистувања во лековите за настинка, грип и кашлица, што би бил применлив кај голем број на можни формулации на оваа група на лекови. Супстанциите што можат да бидат разделени со методот вклучуваат единаесет активни супстанции: парацетамол, фенилефрин хидрохлорид, кофеин, ибупрофен, аскорбинска киселина, пропифеназон, фенирамин малеат, хлорфенамин малеат, псеудоефедрин хидрохлорид, декстрометорфан хидробромид и цетилпиридиниум хлорид; пет нивни онечистувања: 4-аминофенол, 4-нитрофенол, 4-хлороацетанилид, хлорфенамин онечистување С и ефедрин хидрохлорид; и два конзерванси: натриум бензоат и пропил парахидроксибензоат. Сите 18 супстанции беа успешно разделени на реверзно-фазна (RP)-HPLC колона со површинско-порозни честички, користејќи градиентно елуирање со примена на многу едноставна мобилна фаза, за време од 14 минути, со одлична осетливост и резолуција. Оптимизацијата на методот беше спроведена со пристапот на дизајн на експерименти. Предложениот метод е валидиран согласно ICH водичите и докажано е дека е соодветен за истовремено квалитативно и квантитативно определување на избраните супстанции кај различни дозирани форми на лекови за настинка, грип и кашлица. 
